
2 Research Square
Preprints are preliminary reports that have not undergone peer review.
They should not be considered conclusive, used to inform clinical practice,
or referenced by the media as validated information.

\title{
Psychosocial impact of respiratory infectious disease pandemics on children: a systematic review
}

\author{
Chenran Wang \\ Centers for Disease Control and Prevention \\ Shuyue Xiao \\ Chinese Center for Disease Control and Prevention \\ Yijie Sun \\ Chinese Center for Disease Control and Prevention \\ Jinpeng Wang \\ Chinese Center for Disease Control and Prevention \\ Tao Xu ( $\nabla$ xuta06622@chinawch.org.cn) \\ Shanxi Center for Disease Control and Prevention
}

\section{Research}

Keywords: COVID-19, mental health, behavior, parenting

Posted Date: July 20th, 2020

DOI: https://doi.org/10.21203/rs.3.rs-41460/v1

License: @ (i) This work is licensed under a Creative Commons Attribution 4.0 International License. Read Full License 


\section{Abstract \\ Objective}

To examine the impact of respiratory infectious disease pandemics in the new millennium on mental health, behavioral responses, and parenting practices in children, and provide further intervention directions to mitigate negative effects of the 2019 novel coronavirus disease (COVID-19).

\section{Methods}

We conducted a systemic literature review of researches from January 2003 to May 2020 with three mainstream electronic databases including PubMed, Web of Science, and China National Knowledge Infrastructure. Quality of included studies were assessed using Agency for Healthcare Research and Quality (AHRQ), Newcastle-Ottawa Scale (NOS), and Critical Appraisal Skills Programme (CASP) according to different study design. Further directions were identified for developing appropriate interventions.

\section{Results}

Twenty-four studies conducted in the context of severe acute respiratory syndrome (SARS) $(n=10)$, influenza A (H1N1) ( $n=3)$, and COVID-19 ( $n=11)$ pandemics met the inclusion criteria. Children showed emotional conditions such as anxiety, fear, and depression, while psychological responses varied across age and gender groups. Children with mental illness history experienced an exacerbation of psychological symptoms. The pandemics changed hygiene habits and learning styles, and led to the increased participation in unfavorable lifestyles. For families with pediatric patients, the pandemic decreased parents' participation in providing family-centered care and threatened to supportive family relationship and effective parents-child communication.

\section{Conclusion}

The emerging virus outbreaks and subsequent disease-control measures have impacts on mental health status, behavioral responses, and parenting practices in children. In response to COVID-19, greater efforts taking into account children's developmental stage should be made to implement evidence-based psychological interventions, enhance effective communication, and encourage collaboration.

\section{Introduction}

Since the 2019 novel coronavirus disease (COVID-19) pandemic was declared in early March 2020, affected countries have been reporting their epidemiolocial data in close succession. ${ }^{1,2}$ As of June 30,2020 , there were more than 10.1 million COVID-19 cases worldwide, with the death toll rising to 0.5 million. In response to the COVID-19 outbreak, health authorities across the globe have launched a series of infection control measures including mobility restriction, school closure, home confinement, and quarantine/isolation for those with suspected/confirmed infection. Although the risk of infection has been effectively controlled, these mandatory public health strategies may have short- and long-term impacts on psychological state, behaviors, and family life ${ }^{3,4}$, particularly in children who are in a vulnerable position in response to public health emergencies and have limited abilities to cope with their psychological issues. ${ }^{5}$

It is estimated that approximate 1.5 billion young people are out of education due to school closures; most of them are confined to their homes and are discouraged from public activities. ${ }^{4,6}$ For quarantined children who are infected with the disease or have close contact with confirmed patients, separation from parents and family members' death make them more likely to develop psychosocial disorders. ${ }^{7}$ Evidence has also indicated that psychological stress and economic impact of public health emergencies can increase the parenting hardship. ${ }^{8}$ However, most of the published literature on similar respiratory infectious disease pandemics in the new millennium, such as the outbreak of severe acute respiratory syndrome (SARS) in 2003, influenza A (H1N1) in 2009, and Middle East respiratory syndrome (MERS) in 2012, paid much attention on medical needs of patients, with the psychosocial impacts among children arousing insufficient attention. ${ }^{9-11}$

In order to fully understand the psychosocial impact of COVID-19 pandemic and other similar events among children, we performed a systematic review of studies assessing the impact of emerging respiratory infectious disease outbreaks on mental health, behaviors, and parenting practices for children. Based on the evidence obtained from the comprehensive analysis, suggestions on further directions were made to inform health systems of tailored intervention strategies to improve children's well-being.

\section{Methods}

\section{Inclusion and exclusion criteria}

\section{Context of diseases and health outcomes}

The respiratory infectious disease pandemics sharing similar public health significance in the new millennium including SARS, influenza H1N1, MERS, and COVID-19 were included in this review. Studies must reveal the association between disease outbreaks and children's responses; the three main concepts of the psychosocial impacts were restricted to mental status, behavioral patterns, and parenting practices.

\section{Types of participants}


The review included participants aged < 18 years who experienced home confinement, quarantine, and isolation due to the above pandemics. Norm children, pediatric patients with suspected/confirmed infection, and those diagnosed with other diseases (such as pre-existing mental disorders,obesity, etc) were enrolled.

\section{Types of studies}

Original researches were eligible if the study performed quantitative and/or qualitative analyses. Those focusing on pathology, diagnosis, and treatment of diseases, systematic reviews, correspondence, and comments/editorials were excluded.

\section{Search Strategy}

We searched PubMed, Web of Science, and China National Knowledge Infrastructure for related publications dated within the past 17 years (January $2003-$ June 2020), using keyword combinations of the following three categories: respiratory infectious diseases (Serious Acute Respiratory Symptom, SARS, influenza H1N1, Middle East Respiratory Syndrome, MERS, 2019 novel coronavirus disease, and COVID-19), participants (children, child, adolescents, and youth), and health outcomes (psychosocial situation, psychological situation, mental health, social behaviors, parenting practices, nurturing care, and early development). More details are listed in the Additional file 1. The reference lists of inclued studies were also reviewed. Citations were downloaded to NoteExpress and duplicates were removed. The process of study search and selection is shown in Fig. 1.

\section{Data Collection And Analysis Selection of studies}

The first author screened titles and abstracts of literature according to the search strategy. The full-text of studies were independently reviewed by the first and second author, and were identified to be included or excluded. Disagreements were resolved by all authors through discussion and consensus.

\section{Data extraction and management}

The following information from included studies were extracted using a structured work sheet: (1) study characteristics (ie, first author, publication year, country/ region, study design, sampling method, the context of disease, research method, scale, main findings, and conclusion); (2) participant characteristics (ie, health status, age, and sample size).

\section{Assessment of quality of included studies}

We assessed quality of cross sectional and follow-up studies using the Agency for Healthcare Research and Quality (AHRQ) $)^{12}$, where studies received summary scores of low (0-3 points), medium (4-7 points), and high (8-11 points). The Newcastle-Ottawa Scale (NOS) ${ }^{13}$ was performed to assess quality of the case-control study, and Critical Appraisal Skills Programme (CASP) ${ }^{14}$ checklists were used to appraise qualitative studies, with a higher score indicating better quality. Consensus was reached on all included studies.

\section{Measure of impact}

No calculations were performed. Quantitative data was presented in the format of mean and standard deviation (SD) with $95 \%$ confidence intervals (CI), proportion, and rate, if provided. Results with $P>0.05$ were reported as not significant. Descriptive narratives of qualitative data were summarized to reveal the experiences and recollections of children and caregivers.

This review used the Preferred Reporting Items for Systematic Reviews and Meta-Analysis (PRISMA) ${ }^{15}$ as a guide, and the PRISMA checklist was included in the Additional file 2.

\section{Results}

\section{Study overview}

Twenty-four studies meeting the eligibility criteria were included in this review, with ten studies being conducted in the context of the SARS outbreak, three in influenza A (H1N1), and eleven in COVID-19. Research locations included mainland China (10), Hong Kong Special Administrative Region of China (4), Italy (3), Canada (2), America (2), Netherlands (1), UK (1), and India (1). The studies categorized by topic of interest are shown in Table 1. 
Table 1

Original studies categorized by theme

\begin{tabular}{|c|c|c|}
\hline Focus & Topic & Number \\
\hline \multirow[t]{8}{*}{ Mentality } & Anxiety, fear, depress, and traumatic stress & 5 \\
\hline & Gender disparities in psychological stress & 6 \\
\hline & Age disparities in psychological stress & 3 \\
\hline & Exacerbation of pre-existing mental health disorders & 4 \\
\hline & Emotional needs & 4 \\
\hline & Medium-term psychological effects & 2 \\
\hline & Dual effects of media & 5 \\
\hline & Other impact factors & 3 \\
\hline \multirow[t]{4}{*}{ Behavior } & Hygiene behaviors & 5 \\
\hline & Lifestyle behaviors & 3 \\
\hline & Associations between behavioral motivations and mental health & 1 \\
\hline & Learning adaptability & 1 \\
\hline \multirow[t]{5}{*}{ Parenting } & Separation anxiety & 5 \\
\hline & Emotional connection & 4 \\
\hline & Family relationship & 3 \\
\hline & Family participation & 2 \\
\hline & Communication challenges & 4 \\
\hline
\end{tabular}

\section{Methods Of Included Researches}

Sixteen quantitative and six qualitative studies were identified for inclusion, while the other two studies used a combination of quantitative and qualitative approaches. Of the sixteen quantitative studies, fifteen were cross-sectional studies and one was follow-up study, in which statistical methods were adopted to explore the relationship between the epidemic and psychological responses. Telephone interview, semi-structured interview, and case report were implemented in qualitative studies to identify the health effect on behavioral patterns and parenting practices. Detailed information of each included study are demonstrated in Table 2. 
Table 2

Summary of included studies

\begin{tabular}{|c|c|c|c|c|c|c|c|c|c|}
\hline Citation & Country/region & $\begin{array}{l}\text { Study } \\
\text { design }\end{array}$ & Sampling method & $\begin{array}{l}\text { Children's } \\
\text { health } \\
\text { status }\end{array}$ & Age & $\begin{array}{l}\text { Sample } \\
\text { size }\end{array}$ & $\begin{array}{l}\text { Background } \\
\text { disease }\end{array}$ & Research method & Sc \\
\hline $\begin{array}{l}\text { Meiru Xu et } \\
\text { al., } 2003\end{array}$ & China/Beijing & $\begin{array}{l}\text { Cross- } \\
\text { sectional } \\
\text { study }\end{array}$ & $\begin{array}{l}\text { Simple random } \\
\text { sampling \& } \\
\text { Systematic } \\
\text { sampling }\end{array}$ & Norm & $\begin{array}{l}14 \sim \\
16 \text { years }\end{array}$ & 238 & SARS & Telephone interview & $\mathrm{Nc}$ \\
\hline
\end{tabular}

\begin{tabular}{|c|c|c|c|c|c|c|c|c|}
\hline $\begin{array}{l}\text { Chi-wai Leung } \\
\text { et al., } 2004\end{array}$ & $\begin{array}{l}\text { China/Hong } \\
\text { Kong }\end{array}$ & $\begin{array}{l}\text { Follow-up } \\
\text { study }\end{array}$ & Clinical case & Infected & 18 years & 41 & SARS & $\begin{array}{l}\text { Telephone interview; } \\
\text { Psycho-education; } \\
\text { Psychological } \\
\text { functioning screening }\end{array}$ \\
\hline
\end{tabular}

\begin{tabular}{|c|c|c|c|c|c|c|c|c|}
\hline $\begin{array}{l}\text { Albert M. Li et } \\
\text { al., } 2004\end{array}$ & $\begin{array}{l}\text { China/Hong } \\
\text { Kong }\end{array}$ & $\begin{array}{l}\text { Qualitative } \\
\text { study }\end{array}$ & Not mention & Infected & $\begin{array}{l}7 \sim \\
13 \text { years }\end{array}$ & 4 & SARS & $\begin{array}{l}\text { Semi-structured } \\
\text { interview }\end{array}$ \\
\hline
\end{tabular}

\begin{tabular}{|c|c|c|c|c|c|c|c|c|}
\hline $\begin{array}{l}\text { Xiaoying Lu et } \\
\text { al., } 2005\end{array}$ & China/Beijing & $\begin{array}{l}\text { Cross- } \\
\text { sectional } \\
\text { study }\end{array}$ & Cluster sampling & Norm & $\begin{array}{l}9 \sim \\
16 \text { years }\end{array}$ & 96 & SARS & Telephone interview \\
\hline
\end{tabular}

\begin{tabular}{|c|c|c|c|c|c|c|c|c|c|}
\hline $\begin{array}{l}\text { Hongling } \mathrm{He} \\
\text { et al., } 2005\end{array}$ & China/Xian & $\begin{array}{l}\text { Cross- } \\
\text { sectional } \\
\text { study }\end{array}$ & Random sampling & Norm & $\begin{array}{l}\text { Fourth to } \\
\text { sixth } \\
\text { grades }\end{array}$ & 1811 & SARS & Questionnaire & $\begin{array}{l}\mathrm{Zu} \\
\mathrm{de} \\
\text { (S } \\
\text { rat } \\
\mathrm{sc}\end{array}$ \\
\hline
\end{tabular}

\begin{tabular}{|c|c|c|c|c|c|c|c|c|c|}
\hline $\begin{array}{l}\text { Hongling } \mathrm{He} \\
\text { et al., } 2006\end{array}$ & China/Xian & $\begin{array}{l}\text { Cross- } \\
\text { sectional } \\
\text { study }\end{array}$ & Random sampling & Norm & $\begin{array}{l}\text { Fourth to } \\
\text { sixth } \\
\text { grades }\end{array}$ & 1758 & SARS & Questionnaire & $\begin{array}{l}\mathrm{Zu} \\
\text { de } \\
\text { (S } \\
\text { rat } \\
\text { sc } \\
\text { Ey } \\
\text { Pe } \\
\text { QL } \\
\text { (El }\end{array}$ \\
\hline
\end{tabular}

*E: Extrovision and introvision on Eysenck Personality Questionnaire (EPQ)

Legend: Table 2 shows detailed information of each included study. 


\begin{tabular}{|c|c|c|c|c|c|c|c|c|c|}
\hline Citation & Country/region & $\begin{array}{l}\text { Study } \\
\text { design }\end{array}$ & Sampling method & $\begin{array}{l}\text { Children's } \\
\text { health } \\
\text { status }\end{array}$ & Age & $\begin{array}{l}\text { Sample } \\
\text { size }\end{array}$ & $\begin{array}{l}\text { Background } \\
\text { disease }\end{array}$ & Research method & Sc \\
\hline $\begin{array}{l}\text { Sophia SC } \\
\text { Chan et al., } \\
2007\end{array}$ & $\begin{array}{l}\text { China/Hong } \\
\text { Kong }\end{array}$ & $\begin{array}{l}\text { Qualitative } \\
\text { study }\end{array}$ & With invitation & Suspected & $\begin{array}{l}\text { Not } \\
\text { mention }\end{array}$ & 7 & SARS & $\begin{array}{l}\text { Semi-structured } \\
\text { interview }\end{array}$ & Nc \\
\hline
\end{tabular}

\begin{tabular}{|c|c|c|c|c|c|c|c|c|}
\hline $\begin{array}{l}\text { Donna Koller } \\
\text { et al., } 2010\end{array}$ & Canada & $\begin{array}{l}\text { Qualitative } \\
\text { study }\end{array}$ & $\begin{array}{l}\text { Electronic medical } \\
\text { records }\end{array}$ & $\begin{array}{l}\text { Suspected; } \\
\text { With other } \\
\text { diagnoses }\end{array}$ & $\begin{array}{l}5 \sim \\
19 \text { years }\end{array}$ & 21 & SARS & $\begin{array}{l}\text { Semi-structured } \\
\text { interview; Medical } \\
\text { records }\end{array}$ \\
\hline
\end{tabular}

\begin{tabular}{|c|c|c|c|c|c|c|c|c|c|}
\hline $\begin{array}{l}\text { Danielle } \\
\text { Remmerswaal } \\
\text { et al., } 2011\end{array}$ & Netherlands & $\begin{array}{l}\text { Cross- } \\
\text { sectional } \\
\text { study }\end{array}$ & With invitation & Norm & $\begin{array}{l}7 \sim \\
12 \text { years }\end{array}$ & 223 & $\begin{array}{l}\text { Influenza } \\
\text { H1N1 }\end{array}$ & Questionnaire & $\begin{array}{l}\mathrm{Fe} \\
\mathrm{QL} \\
(\mathrm{F} ! \\
\text { Int } \\
\mathrm{Sv} \\
\text { (S } \\
\mathrm{Su} \\
\text { fo } \\
\mathrm{Re}\end{array}$ \\
\hline
\end{tabular}

\begin{tabular}{|c|c|c|c|c|c|c|c|c|}
\hline $\begin{array}{l}\text { LISA A. PAGE } \\
\text { et al., } 2011\end{array}$ & UK & $\begin{array}{l}\text { Case- } \\
\text { control } \\
\text { study \& } \\
\text { Qualitative } \\
\text { study }\end{array}$ & $\begin{array}{l}\text { Electronic medical } \\
\text { records }\end{array}$ & $\begin{array}{l}\text { With pre- } \\
\text { existing } \\
\text { mental } \\
\text { health } \\
\text { disorders }\end{array}$ & $\begin{array}{l}\text { Not } \\
\text { mention }\end{array}$ & 144 & $\begin{array}{l}\text { Influenza } \\
\text { H1N1 }\end{array}$ & Not mention \\
\hline $\begin{array}{l}\text { Ginny Sprang } \\
\text { et al., } 2012\end{array}$ & $\begin{array}{l}\text { America/Arizona, } \\
\text { California, } \\
\text { Florida, New } \\
\text { York, Texas, } \\
\text { Kentucky; } \\
\text { Mexico/Mexico } \\
\text { City; } \\
\text { Canada/Toronto }\end{array}$ & $\begin{array}{l}\text { Cross- } \\
\text { sectional } \\
\text { study \& } \\
\text { Qualitative } \\
\text { study }\end{array}$ & Not mention & Infected & $\begin{array}{l}\text { Not } \\
\text { mention }\end{array}$ & 398 & $\begin{array}{l}\text { Influenza } \\
\text { H1N1 } \\
\text { (91\%); } \\
\text { SARS (8\%); } \\
\text { Avian } \\
\text { influenza } \\
(1 \%)\end{array}$ & $\begin{array}{l}\text { Questionnaire; Focus } \\
\text { group; Semi- } \\
\text { structured interview }\end{array}$ \\
\hline $\begin{array}{l}\text { Donna F. } \\
\text { Koller et al., } \\
2015\end{array}$ & Canada/Toronto & $\begin{array}{l}\text { Qualitative } \\
\text { study }\end{array}$ & With invitation & Infected & $\begin{array}{l}<6 \\
\text { years; } 6 \\
\sim 18 \\
\text { years; }\end{array}$ & 23 & SARS & $\begin{array}{l}\text { Interviews; Patient } \\
\text { health care record }\end{array}$ \\
\hline
\end{tabular}

\begin{tabular}{|c|c|c|c|c|c|c|c|c|}
\hline $\begin{array}{l}\text { Shaowen Li et } \\
\text { al., } 2020\end{array}$ & China/Shanxi & $\begin{array}{l}\text { Cross- } \\
\text { sectional } \\
\text { study }\end{array}$ & Snowball sampling & Norm & $8 \sim$ years & 396 & COVID-19 & Questionnaire \\
\hline
\end{tabular}




\begin{tabular}{|c|c|c|c|c|c|c|c|c|c|}
\hline Citation & Country/region & $\begin{array}{l}\text { Study } \\
\text { design }\end{array}$ & Sampling method & $\begin{array}{l}\text { Children's } \\
\text { health } \\
\text { status }\end{array}$ & Age & $\begin{array}{l}\text { Sample } \\
\text { size }\end{array}$ & $\begin{array}{l}\text { Background } \\
\text { disease }\end{array}$ & Research method & $\mathrm{Sc}$ \\
\hline $\begin{array}{l}\text { Yue Wang et } \\
\text { al., } 2020\end{array}$ & China/Shanxi & $\begin{array}{l}\text { Cross- } \\
\text { sectional } \\
\text { study }\end{array}$ & Snowball sampling & Norm & $\begin{array}{l}8 \sim \\
18 \text { years }\end{array}$ & 396 & COVID-19 & Questionnaire & $\begin{array}{l}\mathrm{D} \epsilon \\
\text { rat } \\
\mathrm{Ch}\end{array}$ \\
\hline
\end{tabular}

\begin{tabular}{|c|c|c|c|c|c|c|c|c|c|}
\hline $\begin{array}{l}\text { Angelo } \\
\text { Pietrobelli et } \\
\text { al., } 2020\end{array}$ & Italy/Verona & $\begin{array}{l}\text { Cross- } \\
\text { sectional } \\
\text { study }\end{array}$ & Not mention & $\begin{array}{l}\text { With } \\
\text { obesity }\end{array}$ & $\begin{array}{l}6 \sim \\
18 \text { years }\end{array}$ & 41 & COVID-19 & Telephone interview & $\mathrm{S} \epsilon$ \\
\hline
\end{tabular}

\begin{tabular}{|c|c|c|c|c|c|c|c|c|c|}
\hline $\begin{array}{l}\text { Marco Colizzi } \\
\text { et al., } 2020\end{array}$ & Italy/Verona & $\begin{array}{l}\text { Qualitative } \\
\text { study }\end{array}$ & Clinical case & $\begin{array}{l}\text { With pre- } \\
\text { existing } \\
\text { mental } \\
\text { health } \\
\text { disorders }\end{array}$ & 16 years & 1 & COVID-19 & Case report & Nc \\
\hline $\begin{array}{l}\text { Jinsong } \\
\text { Zhang et al., } \\
2020\end{array}$ & China/Shanghai & $\begin{array}{l}\text { Cross- } \\
\text { sectional } \\
\text { study }\end{array}$ & With invitation & $\begin{array}{l}\text { With pre- } \\
\text { existing } \\
\text { mental } \\
\text { health } \\
\text { disorders }\end{array}$ & $\begin{array}{l}6 \sim \\
15 \text { years }\end{array}$ & 241 & COVID-19 & Questionnaires & $\begin{array}{l}\text { Sv } \\
\text { an } \\
\text { thi } \\
\text { Di } \\
\mathrm{Ch}\end{array}$ \\
\hline $\begin{array}{l}\text { Kaiheng Zhu } \\
\text { et al., } 2020\end{array}$ & China/Hubei & $\begin{array}{l}\text { Cross- } \\
\text { sectional } \\
\text { study }\end{array}$ & $\begin{array}{l}\text { Random cluster } \\
\text { sampling }\end{array}$ & Norm & $\begin{array}{l}\text { Second } \\
\text { to sixth } \\
\text { grades }\end{array}$ & 1264 & COVID-19 & Questionnaires & $\begin{array}{l}\mathrm{Sc} \\
\mathrm{Ar} \\
\mathrm{En}\end{array}$ \\
\hline $\begin{array}{l}\text { Kumar } \\
\text { Saurabh et al., } \\
2020\end{array}$ & India/Bihar & $\begin{array}{l}\text { Cross- } \\
\text { sectional } \\
\text { study }\end{array}$ & With invitation & $\begin{array}{l}\text { Potentially } \\
\text { exposed \& } \\
\text { Norm }\end{array}$ & $\begin{array}{l}9 \sim \\
18 \text { years }\end{array}$ & 252 & COVID-19 & Questionnaires & $\mathrm{Nc}$ \\
\hline
\end{tabular}

\begin{tabular}{|c|c|c|c|c|c|c|c|c|c|}
\hline $\begin{array}{l}\text { Benjamin } \\
\text { Oosterhoff et } \\
\text { al., } 2020\end{array}$ & the US & $\begin{array}{l}\text { Cross- } \\
\text { sectional } \\
\text { study }\end{array}$ & Self-selected & Norm & $\begin{array}{l}13 \sim \\
18 \text { years }\end{array}$ & 683 & COVID-19 & Questionnaires & $\begin{array}{l}\mathrm{Pa} \\
\mathrm{O} \\
\mathrm{M} \\
\text { Int } \\
\text { Sy } \\
\text { an } \\
\mathrm{Sc} \\
\text { Int } \\
\mathrm{N} \epsilon \\
\mathrm{Ql}\end{array}$ \\
\hline
\end{tabular}




\begin{tabular}{|c|c|c|c|c|c|c|c|c|c|}
\hline Citation & Country/region & $\begin{array}{l}\text { Study } \\
\text { design }\end{array}$ & Sampling method & $\begin{array}{l}\text { Children's } \\
\text { health } \\
\text { status }\end{array}$ & Age & $\begin{array}{l}\text { Sample } \\
\text { size }\end{array}$ & $\begin{array}{l}\text { Background } \\
\text { disease }\end{array}$ & Research method & Sc \\
\hline $\begin{array}{l}\text { Marco Colizzi } \\
\text { et al., } 2020\end{array}$ & Italy/Verona & $\begin{array}{l}\text { Cross- } \\
\text { sectional } \\
\text { study }\end{array}$ & With invitation & $\begin{array}{l}\text { With pre- } \\
\text { existing } \\
\text { mental } \\
\text { health } \\
\text { disorders }\end{array}$ & $\begin{array}{l}13 \pm \\
8.1 \text { years }\end{array}$ & 527 & COVID-19 & Questionnaires & $\mathrm{Nc}$ \\
\hline $\begin{array}{l}\text { Shengyi Liu et } \\
\text { al., } 2020\end{array}$ & China/Sichuan & $\begin{array}{l}\text { Cross- } \\
\text { sectional } \\
\text { study }\end{array}$ & Cluster sampling & Norm & $\begin{array}{l}\text { Fifth and } \\
\text { sixth } \\
\text { grades }\end{array}$ & 209 & COVID-19 & Questionnaires & $\begin{array}{l}\text { Sc } \\
\text { ra }\end{array}$ \\
\hline $\begin{array}{l}\text { Shao } \\
\text { Shanshan et } \\
\text { al., } 2020\end{array}$ & China/Wuxi & $\begin{array}{l}\text { Cross- } \\
\text { sectional } \\
\text { study }\end{array}$ & Cluster sampling & Norm & $\begin{array}{l}4.99 \pm \\
0.9 \text { years }\end{array}$ & 2370 & COVID-19 & Questionnaires & Se \\
\hline
\end{tabular}

*E: Extrovision and introvision on Eysenck Personality Questionnaire (EPQ)

Legend: Table 2 shows detailed information of each included study.

\section{Quality Of Included Researches}

For the fifteen cross-sectional studies, twelve were considered to be of medium quality and three were high quality. The scores of qualitative studies ranged between 7 and 10 points, which indicated high levels of research quality, as did that of the two studies performing a combination of quantitative and qualitative approaches. The results of quality assessment for each included study in detail were shown in the Additional file $\mathbf{3}$. The risk assessment of potential bias for the present study as a whole was not applied because of the inconsistency of study design across studies.

\section{Psychological Impact}

\section{Anxiety, fear, depression, and traumatic stress}

The pandemics had negative psychological impacts on children. For children experiencing quarantine or isolation during the disease pandemic, anxiety was the most common psychological problem. ${ }^{16,17}$ A cross-sectional study in Shanxi Province of northwestern China found during the home confinement of COVID-19 outbreak, $22 \%$ and $10.4 \%$ of primary school students showed anxiety and depression symptoms, respectively. ${ }^{18}$ Depression was positively correlated with anxiety $(O R: 4.28 ; 95 \% \mathrm{Cl}: 2.16,8.49)$ and fear of COVID-19-related information $(O R: 3.31 ; 95 \% \mathrm{Cl}: 1.21,9.06) .{ }^{19}$ In addition, Ginny et al. observed significant differences in traumatic stress between children who did and did not experience isolation, with those who were quarantined due to SARS and influenza H1N1 showing post traumatic stress disorder (PTSD)-related symptoms and received PTSD diagnosis at higher rates. ${ }^{16}$ Children's concern for life and health regarding COVID-19 was found to be related to the incidence of somatic symptoms. ${ }^{20}$

\section{Gender disparities in psychological stress}

Many investigations observed significant discrepancies in psychological responses to pandemics between genders. A case-control survey conducted in Beijing during the SARS outbreak showed boys had higher levels of neurastheria, compulsion, fear, depression, and negativity compared with girls $(P<0.05) .{ }^{21,22}$ However, using a logistic regression model, Li et al. and Zhu et al. found girls had an increased likelihood of being anxious (OR=2.26 and 1.4 , respectively) during the COVID-19 outbreak, ${ }^{17,18}$ which indicated that being more sensitive to pandemic-related coverage may exacerbate girls' psychological stress. ${ }^{23,24}$ 
A significant correlation with psychological impacts was present for age. Based on Zung's self-rating depression scale (SDS) and Zung's self-rating anxiety scale (SAS), a quantitative investigation conducted in the context of SARS epidemic suggested that scores on dimensions of depression and passiveness in sixth-grade schoolchildren exceeded those from other grades. ${ }^{22}$ Similarly, older children appeared less fear of medical affairs, such as medical personal protective equipment (PPE), than younger children when they were hospitalized due to the 2009 influenza HIN1 pandemic. ${ }^{24}$ However, a study in China showed that age was positively correlated with emotional depress $(\beta=0.181)$, with senior high school students getting the highest score on the dimension of depression in a self-rating scale. ${ }^{19}$

\section{Exacerbation of pre-existing mental health disorders}

Fearing of infection exacerbated pre-existing mental illness. A case-control study based on electronic records concluded that children with obsessive compulsive disorders had a higher likelihood (OR: 8.1; 95\% Cl: 3.0,21.3) of expressing moderate/severe concerns about influenza virus than the norm peers. ${ }^{25}$ Children who had a history of somatic symptom disorder (SSD), autism spectrum disorder (ASD), and attention deficit hyperactivity disorder (ADHD) were also reported to experience an exacerbation of psychological symptoms. ${ }^{26-28}$

\section{Emotional needs}

When children were isolated in the hospital, their psychological responses could be emotionally influenced by medical staff. ${ }^{29}$ For instance, playthings and developmental games provided by medical workers could partly meet the emotional needs of pediatric patients, by which children's attention was diverted and the loneliness was handled. ${ }^{29}$ Additionally, encouragement from peers made pediatric patients be more aware of the importance of friendship and social support. ${ }^{24,30}$ As Albert M. Li et al. found, the active interaction with new friends brought independence and courage to SARS-affected children during the hospitalization. ${ }^{30}$ For children with pre-existing mental disorders, in-home healthcare support and center-based healthcare support were the two leading reported needs to manage their psychological distress. ${ }^{28}$

\section{Medium-term psychological effects}

Pediatric patients with confirmed infection experienced more obvious psychological impacts than norm children. ${ }^{30}$ A follow-up survey revealed that some young people who were recovered from SARS experienced temporary decreases in attention and memory, transient emotional instabilities, and emotional depress at 1 and 3 months after hospital discharge. ${ }^{31}$ But the short-term to medium-term psychological outcomes among pediatric patients were not evident. $^{31}$

\section{Dual effects of the media}

Multimedia techniques provided hospitalized children with emotional supports and eased emotional distress. ${ }^{32}$ Most school children who were confined to their homes during the pandemic used online education resources to meet the educational requirements. ${ }^{33}$ However, the mass media may also be considered a source of concern. ${ }^{24,25}$ The young were susceptible to social media coverage because they worried that the bad events reported in media would fall on their family, which dramatically triggered anxiety and panic. ${ }^{25,29}$

\section{Other impact factors}

Individual personality, parents' occupation, and residence were also corresponded to children's psychological responses. Emotional instability was associated with increased psychological disorders, and the incidences of neurasthenia and hypochondriasis in children having extroverted personalities were much lower than those with introverted character. ${ }^{22}$ By applying a self-rating scale, He et al. found that school students whose mother were medical staff got higher scores in dimensions of neurasthenia, fear, and depression. ${ }^{21}$ Compared to children dwelling in urban, those in suburban and rural areas had an increased risk of depression (OR: 2.38; $95 \%$ Cl: $1.12,5.07) .{ }^{19}$

\section{Behavioral Impact}

\section{Hygiene behaviors}

The pandemic may improve children's hygiene behaviors. ${ }^{23}$ Compared with the pre-pandemic period, children were more likely to collect epidemic information, focus on personal hygiene, cancel planned appointments, and avoid going to public places ${ }^{25,29}$ But the proportion of children who were compliant with all protective measures was low $(7.43 \%)$, and being prohibited from going out to socialize was the most difficult instruction for children to comply with. ${ }^{34}$ The emerging virus outbreak may have adverse impacts on children with neurodevelopmental disorders. The outbreak of influenza H1N1 aggregated compulsive behaviors of the young with obsessive compulsive disorder (OCD), such as exaggerated hand washing and door handles cleaning. ${ }^{25}$

\section{Lifestyle behaviors}

Children's daily routine and healthy movement were affected by school closures. ${ }^{35}$ A longitudinal observational study in Italy suggested that the obese kids underwent unfavorable changes in dietary habits, increased sleep and screen time, and decreased participation in outdoor activities during the COVID-19 pandemic. ${ }^{36}$ Compared with the pre-COVID-19 pandemic period, $65.4 \%$ of the enrolled preschool children experienced an increase of 10 min in total screen time per day, while the continuous screen time increased by 5 min in 1444 (60.9\%) participants. ${ }^{37}$

\section{Associations between behavioral motivations and mental health}


Oosterhoff et al. found the association between children's motivations to engage in social distancing during the COVID-19 pandemic and psychological responses. Children's various motivations (such as social responsibility, avoid others sick, avoid being judged, and parental rules) to engage social distancing were closely correlated with anxiety symptoms, depressive symptoms, burdensomeness, and belongingness. ${ }^{38}$

\section{Learning adaptability}

High school students self-rated that they experienced decreased learning efficiency during the SARS outbreak, but no statistically significant differences were observed between students in different grades. However, there were discrepancies in learning satisfaction, with children in senior schools being less satisfied with learning states than those from primary and junior schools. The major reasons for the learning dissatisfaction included unavailable in-person guidance from teachers, lack of interaction with peers, and decreased learning efficiency due to school closures. Importantly, some children improved their self-learning abilities and were more conscious of the value of school life than before. ${ }^{33}$

\section{Parenting Practices Separation anxiety}

Hospitalized children with suspected/confirmed infection expressed dramatically emotional distress due to separation from their family members. ${ }^{29,32}$ In an in-depth semi-structured interview conducted in Canada, most children with suspected SARS felt lonesome and experienced separation anxiety when they were separated from parents. A deep sense of insecurity was also a concern for children when they were left alone during the hospitalization. ${ }^{30,39}$ Additionally, the confliction from the responsibility to obey isolation procedures and fear of being separated from children accelerated parents' concern. ${ }^{40}$

\section{Emotional connection}

Psychological responses between children and parents were positively related. ${ }^{16,30}$ A positive association in PTSD symptoms between parents and children experiencing SARS and influenza H1N1 pandemics was observed, with most pairs meeting the clinical cutoff score for PTSD diagnosis simultaneously. ${ }^{16}$ The transmission of threat information from parents to kids was considered the leading contributor to children's psychological stress. Based on a regression model, Danielle Remmerswaal et al. found that the negative news about influenza H1N1 provided by parents acted as a mediator in the relation of parents' and children's fear, while the discrepancy in transmission patterns was not observed between parents. ${ }^{24}$ Families with ASD children were reported to be under more stress and anxiety than those without neurodevelopmental disorders. ${ }^{28}$

\section{Family relationship}

The mandatory separation between hospitalized children and other family members impeded the establishment of the supportive family relationship and provision of family-centered care. ${ }^{29,32}$ However, a semi-structured interview conducted in Hong Kong demonstrated that the emerging virus outbreak had a positive impact on family relationships. Compared with the pre-pandemic period, pediatric SARS patients were more concerned with the health status of caregivers and it was much easier to establish effective child-parents communication after hospital discharge. ${ }^{30}$

\section{Family participation}

For families with hospitalized pediatric patients, infection control measures decreased family participation in providing family-centered care. ${ }^{39}$ As a retrospective cohort study evaluating the provision of nursing care in the SARS epidemic period showed, family-centered care was disturbed by the forbidden admission to wards. ${ }^{39}$ During the hospitalization, the medical worker acted as a substitute caregiver for children and played an important role in providing essential family-centered care. ${ }^{32}$ The loss of parenting role due to being separated from children also decreased parents' participation. ${ }^{32}$

\section{Communication challenges}

The pandemic outbreaks presented considerable challenges to effective communication between pediatric patients and parents. Because of limited sources of updated information, mobile phones became the only tool available to hospitalized children to communicate with the eternal world and get emotional supports. ${ }^{29,30,32,40}$ In addition, some compulsory infection control measures, such as isolation and PPE-wearing, undermined the effective communication between hospitalized children, family members, and medical workers, which in turn exacerbated fear and depression in children. ${ }^{29,32}$

\section{Discussion}

The COVID-19 outbreak poses increasing threat to health and economy, which has become a global public health challenge. During epidemics, the vulnerable children may suffer "secondary pandemic" as a result of mandatory infection control measures implemented by national health authorities. ${ }^{41}$ Although children who were affected with COVID-19 developed less severe clinical symptoms than adults or seniors with underlying chronic diseases, the psychological stress and behavioral problems caused by the pandemic cannot be ignored. ${ }^{42}$ Besides children's emotional and social vulnerabilities being directly and indirectly affected by diseases, the economic impact of infectious outbreaks on caregivers may lead to the increased parenting hardship and disrupt family's routine life, especially vulnerable families from low-income countries with restrained health resources. ${ }^{4,43,44}$ The need to attenuate the adverse effect of COVID-19 pandemic on children should be considered a high priority for their welfare.

Based on our comprehensive review of early experience of COVID-19 and previous respiratory infectious disease pandemics in 21 st century including SARS and influenza H1N1, we highlight the importance of consideration of children's need when developing intervention strategies targeted to children and caregivers in response to the COVID-19 pandemic. 


\section{Children with pre-existing mental disorders}

Children with neuropsychological developmental disorders are more sensitive to disease-related information and are more likely to display behavioral problems. $^{26,27}$ Guideline-recommended strategies for those with pre-existing mental illness, such as ADHD and ASD, are therefore needed to be reinforced to manage children's disruptive behaviors. ${ }^{45}$ Since national social distancing measures present considerably increased challenges to children with a mental illness history, mental training programs that help healthcare professionals deliver timely psychotherapy to children in poor mental health conditions should be implemented in the face of COVID-19 crisis. ${ }^{46}$ To minimize children's emotional distress and improve their long-term physical and psychological well-being, we also highlight the need of timely surveillance and targeted interventions according to their medical conditions. ${ }^{47}$

\section{Online health services}

The network and smart phone apps popularize the provision of online mental health services in the pandemic situation. ${ }^{48}$ Online mental health courses, psycho-education materials, and psychological consultation according to children's physical and mental characteristics are considered effective psychosocial interventions during the crisis. ${ }^{49,50}$ Therefore, providing telemental health services through online platforms is expected to be extensively developed to meet children's psychological needs. ${ }^{2,51}$ Additionally, psychologists, psychiatrists, and community volunteers are advocated to provide individual counseling and professional assistance via online platforms for confined children during school closures. ${ }^{7,52}$

\section{Information sharing}

For families with children with suspected/confirmed infection, providing family members with updated information about their hospitalized kids' health condition is of great importance to highlight the essential role as caregivers that they played in the process of performing patenting practices and to enhance effective communication. ${ }^{29,32}$ More importantly, keeping children updated pertaining to the accurate explanation of the course of disease can serve as a useful approach to alleviate their psychological stress. ${ }^{2,53}$ The developmental stage and comprehension skills are the two leading considerations when parents conduct an emotion-focused communication with their children. ${ }^{53}$

\section{Collaboration among stakeholders}

During such infectious outbreaks, parents, community workers, and medical personnel should work collaboratively to provide essential family-centered care for affected children, while parenting practices are expected to be improved accordingly. ${ }^{32,48}$ In addition, online parenting resources provided by World Health Organization (WHO) and United Nation's Children's Fund (UNICEF) are encouraged to build a harmonious relationship between parents and children, and to reduce parenting stress during the home confinement. ${ }^{4}$ Overall, it is the responsibility for parents, schools, societies, and health care systems at the national, provincial, and local level to mitigate the negative effects of infectious outbreaks on children.

\section{Strength And Limitations}

Compared with previous pandemics such as SARS and influenza H1N1, COVID-19 spreads more widely in the world. However, not much is known about its health effects on children. Based on current evidence of emerging virus outbreaks, we comprehensively summarized the findings about psychological, behavioral, and parenting impacts, and identified further directions to assist health authorities to enhance the well-being of children. The results can serve as a reference to provide better psychological care and family-based services for children under similar situations.

This review has some limitations. Most original studies included were cross-sectional study and semi-structured interview, where medium- and long-term psychological and behavioral consequences in children cannot be regularly monitored and assessed. In addition, since the incidence and mortality rates of the epidemics varied across locations, and research approaches and study design were inconsistent, potential bias in original articles might prevent accurately examining the health outcomes.

\section{Conclusions}

The emerging virus outbreaks and subsequent disease-control measures have direct impacts on mental health status, behavioral responses, and parenting practices among the pediatric population. In response to COVID-19, greater efforts taking into account children's developmental stage should be made to implement evidence-based psychological interventions, enhance effective communication, and encourage collaboration. This review provides important insights when tailoring targeted strategies to reduce the adverse impact of COVID-19 outbreak on children.

\section{Abbreviations}

COVID-19: 2019 novel coronavirus disease; SARS: severe acute respiratory syndrome; MERS: Middle East respiratory syndrome; SD: standard deviation; Cl: confidence intervals; AHRQ: Agency for Healthcare Research and Quality; NOS: Newcastle-Ottawa Scale; CASP: Critical Appraisal Skills Programme; PRISMA: Preferred Reporting Items for Systematic Reviews and Meta-Analysis; PPE: personal protective equipment ; ADHD: attention deficit hyperactivity disorder; SDS: self-rating depression scale; SAS: self-rating anxiety scale; SSD: somatic symptom disorder; OCD: obsessive compulsive disorder; ASD: autism spectrum disorders; WHO: World Health Organization; UNICEF: United Nation's Children's Fund

\section{Declarations}

\section{Availability of data and materials}


All data analyzed during this study are available in the article and its additional files.

\section{Ethics approval and consent to participate}

Not applicable.

\section{Consent for publication}

Not applicable.

\section{Competing interests}

The authors declare that they have no competing interests

\section{Funding}

None.

\section{Authors' contributions}

Dr. Tao Xu conceptualized and designed the study and critically reviewed and revised the manuscript for important intellectual content. ChenranWang conducted the initial literature search and title /abstract screen, participated in the full-text screen, data extraction, and quality assessment, and drafted the first manuscript. Shuyue Xiao, Yijie Sun, and Jinpeng Wang participated in the full-text screen, data extraction, and quality assessment. All authors approved the final manuscript as submitted and agree to be accountable for all aspects of the work.

\section{Acknowledgements}

The authors would like to thank all children and parents participating in the investigations during the pandemic.

\section{Author details}

${ }^{1}$ National Center for Women and Children's Health, Chinese Center for Disease Control and Prevention, Beijing, China

\section{References}

1. World Health Organization. Statement on the second meeting of the International Health Regulations Emergency Committee regarding the outbreak of novel coronavirus (2019-nCoV) $(2019-\text { ncov })^{\wedge}\left(\right.$ accessed ${ }^{\wedge}$ Mar 20th, 2020,2020). World Health Organization. Statement on the second meeting of the International Health Regulations. (2005) Emergency Committee regarding the outbreak of novel coronavirus (2019-nCoV). https://wwwwhoint/news-room/detail/30-01-2020-statement-on-the-second-meeting-of-the-internationalhealth-regulations-(2005)-emergency-committee-regarding-the-outbreak-of-novel-coronavirus-(2019-ncov)^(accessed^Mar 20th, 2020,2020).

2. Ahmed MZ, Ahmed O, Aibao Z, Hanbin S, Siyu L, Ahmad A. Epidemic of COVID-19 in China and associated Psychological Problems. Asian J Psychiatr. 2020;51:102092.

3. Brooks SK, Webster RK, Smith LE,et al. The psychological impact of quarantine and how to reduce it: rapid review of the evidence. Lancet. 2020;395(10227):912-20.

4. Cluver L, Lachman JM, Sherr L,et al. Parenting in a time of COVID-19. Lancet. 2020;395:(10231):e64.

5. Wagner KD. Addressing the Experience of Children and Adolescents During the COVID-19 Pandemic. J Clin Psychiatry. 2020;81:(3).

6. Lee J. Mental health effects of school closures during COVID-19. Lancet Child Adolesc Health. 2020.

7. Liu JJ, Bao Y, Huang X, Shi J, Lu L. Mental health considerations for children quarantined because of COVID-19. Lancet Child Adolesc Health. 2020;4: (5):347-49.

8. Rothe D, Gallinetti J, Lagaay M, Campbell L. Ebola: beyond the health emergency. Monrovia: Plan International; 2015.

9. Li AM, Ng PC. Severe acute respiratory syndrome (SARS) in neonates and children. Arch Dis Child Fetal Neonatal Ed. 2005;90:(6):F461-65.

10. Alserehi H, Wali G, Alshukairi A, Alraddadi B. Impact of Middle East Respiratory Syndrome coronavirus (MERS-CoV) on pregnancy and perinatal outcome. Bmc Infect Dis. 2016;16:105.

11. Chen $\mathrm{H}$, Guo J, Wang C,et al. Clinical characteristics and intrauterine vertical transmission potential of COVID-19 infection in nine pregnant women: a retrospective review of medical records. Lancet. 2020;395:(10226):809-15.

12. Rostom A, Dube C, Cranney A. Celiac Disease. Rockville (MD): Agency for Healthcare Research and Quality (US).Appendix D. Quality Assessment Forms. http://www.ncbi.nlm.nih.gov/books/NBK35156.

13. Wells G, Shea B, O'Connell D. NewCastle-Ottawa Quallty Assessment Scale-Case Control Studies.http://www.ohri.ca/programs/clinical_epidemiology/oxford.asp.

Page $12 / 14$ 
14. Critical Appraisal Skills. Programme (CASP) qualitative appraisial checklist for qualitative research.https://casp-uk.net/casp-tools-checklists/.

15. Liberati A, Altman DG, Tetzlaff J,et al. The PRISMA statement for reporting systematic reviews and meta-analyses of studies that evaluate health care interventions: explanation and elaboration. Plos Med. 2009;6:(7):e1000100.

16. Sprang G, Silman M. Posttraumatic stress disorder in parents and youth after health-related disasters. Disaster Med Public Health Prep. 2013;7:(1):10510.

17. Zhu KH, Zhou Y, Xie XJ,et al. Anxiety symptom and its associates among primary school students in Hubei province during novel coronavirus diseases 2019 epidemic. Chin J Public Health. 2020;36:(5):673-76.

18. Li SW, Wang Y, Yang YY, Lei XM, Yang YF. Investigation on influencing factors for anxiety related emtional disorders of children and adolescents with home quarantine during the prevalence of cornavirus disease 2019. Chinese Journal of child health care. 2020;28(4):407-10.

19. Wang Y, Yang YY, Li SW, Lei XM, Yang YF. Investigation on status and influencing factors for depression symtom of children and adolescents with home quarantine during the prevalence of novel cornavirus pneumonia. Chinese Journal of child health care. 2020;28(3):277-80.

20. Liu S, Liu Y, Liu Y. Somatic symptoms and concern regarding COVID-19 among Chinese college and primary school students: A cross-sectional survey. Psychiatry Res. 2020;289:113070.

21. He HL, Xi LW, Yang YF. Analysis on Mental Health State of SARS of Medical Workers' Children. Chinese Medical Ethics. 2005;18:(03):39-41.

22. He HL, Liu L, Yang YF. Analysis of Primary Students Mental Health Status During SARS Epidemic in Xi' an City. Practical Preventive Medicine. 2006;13: (01):18-20.

23. Xu MR, Zhang L, Gong LY, Ni HM. Response to the SARS outbreak in 230 ninth grade students in Haidian District, Beijing. Chin J School Health. 2003;24: (6):625-26.

24. Remmerswaal D, Muris P. Children's fear reactions to the 2009 Swine Flu pandemic: the role of threat information as provided by parents. $J$ Anxiety Disord. 2011;25:(3):444-49.

25. Page LA, Seetharaman S, Suhail I, Wessely S, Pereira J, Rubin GJ. Using electronic patient records to assess the impact of swine flu (influenza H1N1) on mental health patients. J Ment Health. 2011;20:(1):60-9.

26. Marco Colizzi R, Bortoletto M, Silvestri,et al. Medically unexplained symptoms in the times of Covid-19 pandemic: a case-report. Brain, Behavior, and Immunity Health. 2020.

27. Zhang J, Shuai L, Yu H,et al. Acute stress, behavioural symptoms and mood states among school-age children with attention-deficit/hyperactive disorder during the COVID-19 outbreak. Asian J Psychiatr. 2020;51:102077.

28. Colizzi M, Sironi E, Antonini F, Ciceri ML, Bovo C, Zoccante L. Psychosocial and Behavioral Impact of CoVID-19 in Autism Spectrum Disorder: An Online Parent Survey. Brain Sci. 2020;10:(6).

29. Koller D, Nicholas D, Gearing R, Kalfa O. Paediatric pandemic planning: children's perspectives and recommendations. Health Soc Care Community. 2010;18:(4):369-77.

30. Li AM, Chan CH, Chan DF. Long-term sequelae of SARS in children. Paediatr Respir Rev. 2004;5:(4):296-99.

31. Leung CW, Kwan YW, Ko PW, Chiu SS, Loung PY, Nai C. Severe Acute Respiratory Syndrome Among Children. Pediatrics. 2004;113:e535.

32. Koller DF, Nicholas DB, Goldie RS, Gearing R, Selkirk EK. When family-centered care is challenged by infectious disease: pediatric health care delivery during the SARS outbreaks. Qual Health Res. 2006;16:(1):47-60.

33. Lu XY, Fang GK. Children's learning adaption during SARS. Chin J of Behavioral Med Sci. 2005;14:(09):838-39.

34. Saurabh K, Ranjan S. Compliance and Psychological Impact of Quarantine in Children and Adolescents due to Covid-19 Pandemic. Indian J Pediatr. 2020:1-05.

35. Guan HY, Okely AD, Farias NA, Cruz BP, Draper CE, Hamdouchi AE. Promoting healthy movement behaviours among children during the COVID-19 pandemic. Lancet Child Adoles Health. 2020.

36. Pietrobelli A, Pecoraro L, Ferruzzi A,et al. Effects of COVID-19 Lockdown on Lifestyle Behaviors in Children with Obesity Living in Verona, Italy: A Longitudinal Study. Obesity (Silver Spring). 2020.

37. Shao SS, Jiang L, Zhang Q, Tang M, Gu YJ, Tao FB. Screen time and associated factors among preschoolers in Wuxi during COVID-19 outbreak. Chin J Sch Health. 2020;41:(5):661 - 63, 667.

38. Oosterhoff B, Palmer CA, Wilson J, Shook N. Adolescents' Motivations to Engage in Social Distancing During the COVID-19 Pandemic: Associations With Mental and Social Health. J Adolesc Health. 2020.

39. Sophia SC, Chan, Daisy YK, Leung, Emmy MY, Wong,et al. Balancing infection control practices and family-centred care in a cohort of paediatric suspected severe acute respiratory syndrome patients in Hong Kong. J Paediatr Child H. 2006;42(1-2):20-7.

40. Chan SS, Leung D, Chui H,et al. Parental response to child's isolation during the SARS outbreak. Ambul Pediatr. 2007;7:(5):401-04.

41. Green P. Risks to children and young people during covid-19 pandemic. BMJ. 2020;369:m1669.

42. Jiao WY, Wang LN, Liu J,et al. Behavioral and Emotional Disorders in Children during the COVID-19 Epidemic. J Pediatr. 2020.

43. Goldman PS, van ljzendoorn MH, Sonuga-Barke E. The implications of COVID-19 for the care of children living in residential institutions. Lancet Child Adolesc Health. 2020.

44. Usher K, Bhullar N, Durkin J, Gyamfi N, Jackson D. Family violence and COVID-19: Increased vulnerability and reduced options for support. Int J Ment Health Nurs. 2020. 
45. Cortese S, Asherson P, Sonuga-Barke E,et al. ADHD management during the COVID-19 pandemic: guidance from the European ADHD Guidelines Group.

Lancet Child Adolesc Health. 2020.

46. Usher K, Durkin J, Bhullar N. The COVID-19 pandemic and mental health impacts. Int J Ment Health Nurs. 2020;29:(3):315-18.

47. Fernandez-Aranda F, Casas M, Claes L,et al. COVID-19 and implications for eating disorders. Eur Eat Disord Rev. 2020;28:(3):239-45.

48. Wang G, Zhang Y, Zhao J, Zhang J, Jiang F. Mitigate the effects of home confinement on children during the COVID-19 outbreak. Lancet. 2020;395(10228):945-47.

49. Liu S, Yang L, Zhang C,et al. Online mental health services in China during the COVID-19 outbreak. Lancet Psychiat. 2020;7:(4):e17-8.

50. Holmes EA, O'Connor RC, Perry VH,et al. Multidisciplinary research priorities for the COVID-19 pandemic: a call for action for mental health science. Lancet Psychiat. 2020.

51. Zhou X, Snoswell CL, Harding LE,et al. The Role of Telehealth in Reducing the Mental Health Burden from COVID-19. Telemed J E Health. 2020;26:

(4):377-79.

52. Li W, Yang Y, Liu ZH,et al. Progression of Mental Health Services during the COVID-19 Outbreak in China. Int J Biol Sci. 2020;16:(10):1732-38.

53. Dalton L, Rapa E, Stein A. Protecting the psychological health of children through effective communication about COVID-19. Lancet Child Adolesc Health. 2020;4:(5):346-47.

\section{Figures}

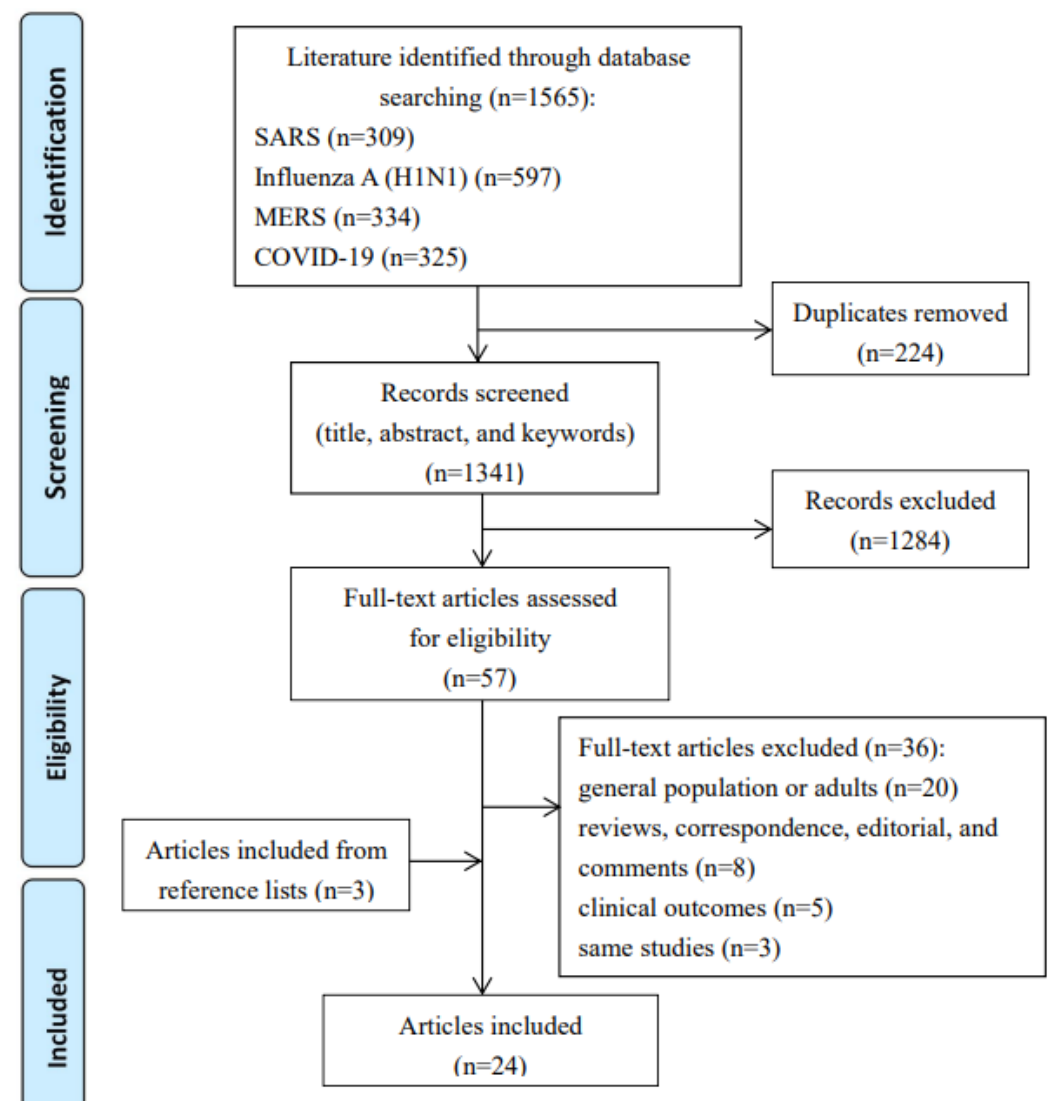

Figure 1. Review flow diagram

\section{Figure 1}

Review flow diagram. The figure shows the process of study search and selection.

\section{Supplementary Files}

This is a list of supplementary files associated with this preprint. Click to download.

- Additionalfile3.docx

- Additionalfile2.docx

- Additionalfile1.docx 